\title{
Expression and regulation of secreted phosphoprotein 1 in the bovine corpus luteum and effects on T lymphocyte chemotaxis
}

\author{
Daniel H Poole ${ }^{1,2,+}$, Kalidou Ndiaye $\mathrm{e}^{1, \neq}$ and Joy L Pate ${ }^{2}$ \\ ${ }^{1}$ Department of Animal Sciences, Ohio Agricultural Research and Development Center, The Ohio State University, \\ Wooster, Ohio 44691, USA and ${ }^{2}$ Department of Animal Science, Center for Reproductive Biology and Health, \\ The Pennsylvania State University, 324 Henning Building, University Park, Pennsylvania 16802, USA \\ Correspondence should be addressed to J L Pate; Email: jlp36@psu.edu
}

${ }^{\dagger} \mathrm{D} \mathrm{H}$ Poole is now at Department of Animal Science, North Carolina State University, Raleigh, North Carolina 27695-7621, USA ${ }^{\ddagger} \mathrm{K}$ Ndiaye is now at Department of Veterinary Biomedicine, University of Montreal, Saint-Hyacinthe, Quebec, Canada J2S 7C6

\begin{abstract}
Secreted phosphoprotein 1 (SPP1) in the bovine corpus luteum $(\mathrm{CL})$ regulates cell function during the transitional periods of luteinization and luteal regression. The objectives were to i) characterize SPP1 expression in the CL throughout the estrous cycle, ii) determine factors that regulate SPP1 expression in luteal cells, and iii) examine the role of SPP1 in lymphocyte chemotaxis, proliferation, and function. SPP1 mRNA was greater in fully functional (d10) CL and late cycle (d18) CL compared with developing (d4) CL. Additionally, SPP1 mRNA increased within $1 \mathrm{~h}$ and remained elevated 4 and $8 \mathrm{~h}$ following induction of luteolysis with prostaglandin (PG) $F_{2 \alpha}$. Expression of the SPP1 receptor, $\beta_{3}$ integrin, was not different throughout the estrous cycle but decreased following induction of luteolysis. Expression of $C D 44$ increased during the estrous cycle but did not change during luteal regression. In cultured luteal cells, SPP1 mRNA was upregulated by $\mathrm{PGF}_{2 \alpha}$ and/or tumor necrosis factor $\alpha$. Western blots revealed the presence of both full-length SPP1 and multiple cleavage products in cultured luteal cells and luteal tissue. Depletion of endogenous SPP1 did not hinder luteal cell-induced lymphocyte proliferation or lymphocyte phenotype but did inhibit lymphocyte migration toward luteal cells. Based on these data, it is concluded that SPP1 is initially activated to establish and maintain cellular interactions between steroidogenic and nonsteroidogenic cells during the development of the CL. Upon induction of luteolysis, SPP1 serves as a signaling molecule to recruit or activate immune cells to facilitate luteal regression and tissue degradation.

Reproduction (2013) 146 527-537
\end{abstract}

\section{Introduction}

The corpus luteum (CL) is a unique endocrine organ with a transient lifespan that undergoes extensive tissue remodeling during luteinization and luteal regression. Luteinization is a dynamic process involving simultaneous hyperplasia, hypertrophy, and differentiation of steroidogenic cells as well as proliferation and migration of nonsteroidogenic cells, within the first 5-7 days following ovulation (Zheng et al. 1994). The CL of ruminants has a finite lifespan and will remain present on the ovary only until a specific signal, prostaglandin $(\mathrm{PG}) \mathrm{F}_{2 \alpha}$, initiates luteal regression at the end of the estrous cycle or pregnancy. Luteolysis involves loss of progesterone $\left(\mathrm{P}_{4}\right)$ production and cellular integrity that ultimately leads to destruction of the CL (Pate 1994, Niswender et al. 2000). Immune cells and cytokines are thought to be involved in luteal formation and regression in a variety of species (Brännström \& Norman 1993,
Pate \& Keyes 2001). Understanding the mechanisms that regulate these critical periods and the role of immune cells in the CL will lead to new and innovative ways to control the estrous cycle and potentially enhance reproductive efficiency.

Secreted phosphoprotein 1 (SPP1), also known as osteopontin and early $\mathrm{T}$ lymphocyte activation 1 , is a secreted, extracellular matrix protein that is abundant in many different cells of mesodermal and endodermal origin (Franzen \& Heinegard 1985, Patarca et al. 1989, O'Regan \& Berman 2000, Sodek et al. 2000, Denhardt et al. 2001). Binding of SPP1 to its receptors, CD44 or several integrins, initiates cell-specific signaling that activates a variety of cellular functions such as tissue remodeling, activation of extracellular matrix proteins to induce cell migration or attachment, regulation of cellmediated immunity, and alteration of cytokine synthesis (reviewed by Sodek et al. (2000)). Several reports have 
shown that SPP1 increases tumor cell angiogenesis in mice (Takahashi et al. 2002, Hirama et al. 2003) and enhances vascularization in ectopic bone (Asou et al. 2001). Xie et al. (2001) demonstrated that an increase in SPP1 is associated with proliferation and regeneration of renal tubular epithelial cells following renal toxic or ischemic injury. Silencing of SPP1 markedly decreased the cell motility and invasiveness of SK-Hep-1 tumor cells (Cheng et al. 2007) and metastasis of murine colon adenocarcinoma (Wai et al. 2005).

SPP1 has been shown to be highly expressed by activated macrophages, dendritic cells, and lymphocytes early in an immune response (Patarca et al. 1989, O'Regan \& Berman 2000). Secretion of SPP1 by nonimmune cells and activated $\mathrm{T}$ cells enhanced recruitment and activation of macrophages and prolonged the immune response (O'Regan et al. 1999). Ashkar et al. (2000) demonstrated that SPP1 increased IL12 and suppressed IL10 production by macrophages, acting through integrin $\alpha_{v} \beta_{3}$ and CD44 receptors respectively. Further studies have demonstrated that SPP1 stimulates interferon $\gamma$ and CD40 ligand expression on antigen-presenting cells, suggesting that SPP1 has a role in the proinflammatory immune response $\left(\mathrm{O}^{\prime}\right.$ Regan \& Berman 2000, Denhardt et al. 2001).

In female reproductive tissues, this multifunctional protein has been identified in the ovary (Craig \& Denhardt 1991, Brown et al. 1992, Brunswig-Spickenheier \& Mukhopadhyay 2003), endometrium (Brown et al. 1992, Johnson et al. 2000, 2001, 2003), oviduct (Brown et al. 1992, Gabler et al. 2003), and ovarian cancers (Kim et al. 2002). $P_{4}$ and unknown conceptus-derived factors upregulate SPP1 in the glandular epithelium, which promotes trophectoderm cell migration and attachment to luminal epithelium and may be essential for conceptus development (Dunlap et al. 2008, Erikson et al. 2009, Kim et al. 2010). In the bovine ovary, SPP1 mRNA was present in granulosa, theca, and luteal cells (BrunswigSpickenheier \& Mukhopadhyay 2003); however, the precise role of SPP1 and its relationship with immune cells within the $C L$ remains unknown. Therefore, the basis of this research was to investigate a potential role of SPP1 in the bovine $\mathrm{CL}$ and its ability to direct lymphocyte responses. It was hypothesized that SPP1 produced by luteal cells modifies lymphocyte responses within the developing, fully functional, and regressing $\mathrm{CL}$.

\section{Materials and methods}

\section{Reagents}

Powdered Hams F-12 culture medium, gentamicin, insulintransferrin-selenium (ITS) premix, fetal bovine serum, SuperScript II Reverse Transcriptase, and TRIzol reagent were purchased from Invitrogen Corporation. Recombinant RNasin and dNTPs were purchased from Promega. Oligonucleotide primers were obtained from Operon-Eurofins (Huntsville, AL, USA).
DyNAmo HS SYBR Green qPCR kits were purchased from MJ Research (Waltham, MA, USA). QIAquick gel extraction kit was purchased from Qiagen Sciences. Type I collagenase was purchased from Worthington Biochemical Corporation (Lakewood, NJ, USA). Avidin/biotin blocking kit and biotinylated goat anti-rabbit IgG secondary antibody were purchased from Vector Laboratories (Burlingame, CA, USA). Bovine luteinizing hormone (LH; AFP II 743B) was provided by the National Hormone and Peptide Program and AF Parlow (Torrence, CA, USA). Milk-derived bovine SPP1 was purchased from R\&D Systems (Minneapolis, MN, USA). Agarose was acquired from Amresco (Solon, OH, USA). Tissue culture flasks were from Corning (Corning, NY, USA). Anti-SPP1 polyclonal antibody (cat. no. ab14175) was purchased from Abcam (Cambridge, MA, USA), while peroxidase-labeled anti-rabbit secondary antibody and the ECL PLUS Western Blotting Analysis System were purchased from GE Healthcare (Piscataway, NJ, USA). Lentiviral particles directed toward the bovine SPP1 sequence (accession no. NM_174187) and scrambled sequence control were purchased from Santa Cruz Biotechnology, Inc. All antibodies for flow cytometry were purchased from VMRD, Inc. (Pullman, WA, USA) or AbD Serotec (Raleigh, NC, USA). Unless otherwise specified, all other chemicals, reagents, and supplies were purchased from Sigma Chemical Co. or VWR Scientific Products (West Chester, PA, USA).

\section{Animals and tissue collection}

Dairy cows exhibiting normal estrous cycles were used in accordance with protocols approved by the Institutional Laboratory Animal Care and Use Committee at The Ohio State University and The Pennsylvania State University. CLs were removed via transvaginal incision at day 4 or 5 (developing), days 10-12 (fully functional), and day 18 (late cycle) of the estrous cycle. Additional CLs were collected 0.5, $1,4,8$, and $12 \mathrm{~h}$ after a luteolytic injection of $\mathrm{PGF}_{2 \alpha}(25 \mathrm{mg})$ was administered at days 10-12 of the estrous cycle. Each $\mathrm{CL}$ was immediately quartered. Then one quarter was frozen in liquid $\mathrm{N}_{2}$ and another quarter was placed in Optimal Cutting Temperature fixative (O.C.T.; Sakura Finetek USA, Inc., Torrance, CA, USA) prior to freezing in liquid $\mathrm{N}_{2}$. Frozen samples were stored at $-80{ }^{\circ} \mathrm{C}$ until further processing. The remaining two quarters were placed into ice-cold Hams F-12 media during transport to the laboratory to be dissociated for culture experiments.

\section{Isolation of T lymphocytes}

Jugular venous blood $(500 \mathrm{ml})$ was collected to isolate peripheral blood mononuclear cells (PBMC), and peripheral T lymphocytes as described previously by Ndiaye et al. (2008). In brief, PBMC were obtained by centrifugation over FicollPaque and T lymphocytes were separated immunomagnetically using the AutoMACS Cell Separator (Miltenyi Biotec, Auburn, CA, USA). T-cell purity was assessed by fluorescent labeling of the T-cell receptor (TCR, anti-CD3 VMRD, Inc.) and this separation procedure yielded $\sim 95 \%$ pure T lymphocytes. The number of viable $\mathrm{T}$ cells was determined using the Guava ViaCount Flex Reagent in the Guava EasyCyte Plus (Millipore, Billerica, MA, USA). 


\section{Dissociation of corpora lutea}

CLs were collected and dissociation of luteal tissue was performed according to Pate (1993). Luteal tissue was minced and placed in $24 \mathrm{mM}$ HEPES-buffered Ham's F-12 culture medium (Gibco, Invitrogen Corporation) containing 0.5\% BSA (Sigma-Aldrich, Inc.), $20 \mu \mathrm{g} / \mathrm{ml}$ gentamicin (Gentamicin Reagent Solution; Invitrogen Corporation), and $2000 \mathrm{U} / \mathrm{g}$ tissue collagenase type I (Worthington Biochemical Corporation). Following dissociation, luteal cells were resuspended in Ham's F-12 culture medium and cell viability was determined via the Guava ViaCount Flex Reagent in the Guava EasyCyte System (Millipore).

\section{Cell culture}

The luteal cells $\left(3.5 \times 10^{5}\right.$ cells $\left./ \mathrm{ml}\right)$ were treated with $\mathrm{LH}$ $(10 \mathrm{ng} / \mathrm{ml}), \mathrm{P}_{4}(0.5 \mu \mathrm{M})$, aminoglutethimide (AG; $\left.50 \mu \mathrm{g} / \mathrm{ml}\right)$, $\mathrm{PGF}_{2 \alpha}(1,10$, or $100 \mathrm{ng} / \mathrm{ml})$, and tumor necrosis factor (TNF; 5 or $50 \mathrm{ng} / \mathrm{ml}$ ) alone or in combination. These treatment concentrations have been shown to affect bovine luteal cell function in vitro (Pate \& Condon 1989, Benyo \& Pate 1992, Townson \& Pate 1996). After culture, media were removed and luteal cells were harvested to quantify SPP1 mRNA by quantitative PCR (qPCR) or to evaluate SPP1 protein expression via western blot. All cultures were carried out for $72 \mathrm{~h}$ at $37^{\circ} \mathrm{C}$ in serum-free media supplemented with L-glutamine $(200 \mathrm{mM})$ and ITS $(5 \mu \mathrm{g} / \mathrm{ml}$ insulin, $5 \mu \mathrm{g} / \mathrm{ml}$ transferrin, and $5 \mathrm{ng} / \mathrm{ml}$ selenium) and $20 \mu \mathrm{g} / \mathrm{ml}$ gentamicin. All experiments were repeated a total of four times using $\mathrm{CL}$ from different animals.

\section{SPP1 knockdown and validation}

Luteal cells and lymphocytes were incubated in serum-free media overnight at $37^{\circ} \mathrm{C}$ prior to transfection. All transfections were conducted according to the manufacturer's recommendations and transfection efficiency was monitored using lentiviral particles containing green fluorescent protein. Using this procedure, a transfection efficiency of $\geq 72 \%$ was achieved in the luteal cell cultures and a transfection efficiency of $\geq 90 \%$ was achieved in the lymphocyte cultures. Attempts to further increase the transfection efficiency of the primary luteal cell cultures resulted in increased luteal cell apoptosis. To ensure efficient knockdown of SPP1, both cell types were transfected with increasing concentrations of viral infectious units (IFU) directed toward the bovine SPP1 sequence (IFU; $1=12$ 500; $2=25$ 000; and 3=37500 IFU/ $\mu \mathrm{l})$. Immunoblots for SPP1 revealed that the active isoform (45 kDa) of SPP1 in both luteal cells and lymphocytes decreased as viral particle concentration increased with optimal knockdown achieved using $25000 \mathrm{IFU} / \mu \mathrm{l}$. This concentration was used for the remaining experiments. In all knockdown experiments, luteal cells and T cells were transfected separately with either lentiviral particles directed toward SPP1 mRNA or scrambled sequence control in AIM V media containing 0.05\% polybrene for $24 \mathrm{~h}$ at $37^{\circ} \mathrm{C}$. Following lentiviral treatment, cells were washed with serum-containing medium and incubated for $24 \mathrm{~h}$. After this knockdown period, luteal cells and lymphocytes were combined and treated with and without increasing concentrations of SPP1 $(0,50,100$, or $500 \mathrm{ng} / \mathrm{ml}$ ) to determine the effects of SPP1 knockdown on lymphocyte function.

\section{Total RNA extraction and $q P C R$}

Total RNA was extracted from luteal tissues at various stages of the estrous cycle using TRIzol reagent. Total RNA was extracted and cDNA synthesis was performed as described previously by Ndiaye et al. (2008). Forward and reverse primers directed toward Bos taurus SPP1, hyaluronic acid receptor (CD44), $\beta 3$ integrin (ITGB3), IL10, and IL12A are described in Table 1. Glyceraldehyde-3-phosphate dehydrogenase $(G A P D H)$ cDNA fragment was amplified as a constitutively expressed gene, and mRNA from bovine uterus was used as a positive control in this study. Following the RT reaction, qPCR was performed on the MJ Research Opticon 2 (Bio-Rad Laboratories) using the DyNAmo HS SYBR Green qPCR Kit under the following conditions: $95{ }^{\circ} \mathrm{C}$ for $5 \mathrm{~min}, 35$ cycles of $94{ }^{\circ} \mathrm{C}$ for $30 \mathrm{~s}$, 56- $60{ }^{\circ} \mathrm{C}$ for $45 \mathrm{~s}$, and $72{ }^{\circ} \mathrm{C}$ for $60 \mathrm{~s}$, followed by an extra elongation of $5 \mathrm{~min}$ at $72{ }^{\circ} \mathrm{C}$. Annealing temperature was optimized for each primer set. The qPCR amplification products were electrophoretically separated on $1.5 \%$ agarose gels and visualized with ethidium bromide under u.v. light to ensure a specific band corresponding to the size of the expected cDNA fragment. Specific bands were extracted and purified using the QIAquick Gel Extraction Kit (Qiagen Sciences) to be used for sequence confirmation. A control sample that was not reverse transcribed was used to confirm that the product obtained was not amplified from genomic DNA. For each gene of interest, a standard curve was prepared from purified CDNA PCR product and used to calculate the relative steady-state concentrations of respective mRNAs in triplicate wells for each sample. These data are presented as mRNA concentrations in arbitrary units.

\section{Protein extraction and immunoblotting}

Proteins were extracted from either luteal tissues or cultured luteal cells using the CelLytic MT Cell Lysis Reagent (SigmaAldrich Biotechnology) in the presence of the protease inhibitor cocktail (Sigma-Aldrich Biotechnology) following the manufacturer's protocol. Quantification of proteins was performed according to Bradford protein analysis (Bradford 1976). Protein samples were subjected to electrophoresis on a $12 \%$ SDS-polyacrylamide gel and separated proteins were blotted onto PVDF membranes (Hybond-P, Amersham Pharmacia Biotech). After $12 \mathrm{~h}$ of incubation in blocking solution (PBS, pH 7.4, 0.1\% Tween 20, 5\% heat-inactivated normal goat serum, $3 \% \mathrm{BSA}$ ) at $4{ }^{\circ} \mathrm{C}$, membranes were washed once for $20 \mathrm{~min}$ in TBS-Tween 20 (20 mM Tris, pH 7.4, $150 \mathrm{mM} \mathrm{NaCl}$, and $0.05 \%$ Tween 20). Membranes were then incubated with anti-SPP1 polyclonal antibody at a final concentration of $0.5 \mu \mathrm{g} / \mathrm{ml}$ in blocking solution at room temperature for $2 \mathrm{~h}$. The membrane was washed three times, 20 min each, in TBS-Tween 20 and then incubated with the HRP-labeled anti-rabbit secondary antibody at a dilution of 1:20 000. The antigen-antibody complex was visualized using 
Table 1 Primers directed toward Bos taurus mRNA targets and validated for use with quantitative PCR analysis.

\begin{tabular}{|c|c|c|c|}
\hline Target & GenBank accession no. & Primer sequences & Amplicon size \\
\hline$C D 44$ & NM_174013 & 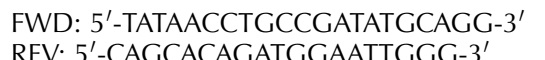 & 221 \\
\hline GAPDH & NM_00103403 & $\begin{array}{l}\text { FWD: } 5^{\prime} \text {-AAGATTGTCAGCAATGCC-3' } \\
\text { REV: } 5^{\prime} \text {-ACAGACACGTTGGGAG-3' }\end{array}$ & 198 \\
\hline IL10 & NM_174088 & $\begin{array}{l}\text { FWD: 5'-TGTTGACCCAGTCTCTGCTG-3' } \\
\text { REV: } 5^{\prime} \text {-CCCTCTCTTGGAGCTCACTG-3' }\end{array}$ & 246 \\
\hline IL12A & U14416 & $\begin{array}{l}\text { FWD: } 5^{\prime} \text {-GAGGCCTGTTTACCACTGGA-3' } \\
\text { REV: } 5^{\prime} \text {-CCTGCATCAGCTCAGCAATA-3' }\end{array}$ & 254 \\
\hline ITGB3 & XM_616376 & $\begin{array}{l}\text { FWD: } 5^{\prime} \text {-TGAGGAGGTGAAGAAGCAGA-3' } \\
\text { REV: } 5^{\prime} \text {-GGTGGTGGAGGCAGAATAAT-3' }\end{array}$ & 247 \\
\hline SPP1 & NM_174187 & $\begin{array}{l}\text { FWD: 5'-CGATGATGATAACAGCCAGG-3' } \\
\text { REV: 5'-ACTCGTCTTCTTAGGTGCGT-3' }\end{array}$ & 328 \\
\hline
\end{tabular}

the ECL system following the manufacturer's protocol. Membranes were exposed for various times to Kodak Biomax light films and the films were developed in a SRX-101A Konica film processor (Konica Corporation). In all blots, proteins extracted from bovine uterus were used as a positive control. $\beta$-actin (ACTB) protein used as an internal control was recognized in all samples by the monoclonal anti-ACTB antibody.

\section{Immunohistochemistry}

Antibody to bovine SPP1 (rabbit polyclonal anti-SPP1) was used to localize SPP1 protein in paraffin sections of luteal tissue collected at previously identified times in the estrous cycle ( $n=4 \mathrm{CL}$ per functional state). The tissues were processed, embedded in paraffin, and sectioned at a thickness of $6 \mathrm{~mm}$. Slides were prepared for staining as described previously by Bove et al. (2000). The tissue sections were incubated for $1 \mathrm{~h}$ at room temperature with rabbit polyclonal anti-SPP1 $(5 \mu \mathrm{g} / \mathrm{ml})$ antiserum in PBS-1\% BSA. After washing, the sections were incubated with a 1:200 dilution of biotinylated goat anti-rabbit IgG secondary antibody for $30 \mathrm{~min}$ at room temperature. The presence of SPP1 was detected using an avidin-biotinperoxidase kit, and diaminobenzidine (Vector Laboratories) was used as the substrate for the enzyme reaction. To confirm positive staining of SPP1, negative controls consisted of omission of the primary antibody or replacement of the primary antibody with nonimmune rabbit IgG. Tissue sections were examined using an Olympus BX51 microscope equipped with an Olympus reflected fluorescence system. Images were collected using an Olympus MagnaFire digital camera.

\section{T lymphocyte proliferation}

Lymphocytes were loaded with $2.5 \mu \mathrm{M}$ carboxyfluorescein succinimidyl ester according to the manufacturer's protocol and as described by Sathiyaseelan \& Baldwin (2000). Lymphocytes were placed either in culture with increasing concentrations of bovine SPP1 or in coculture with luteal cells containing increasing concentrations of bovine SPP1 (SigmaAldrich) and T-cell proliferation was analyzed after $24 \mathrm{~h}$ using Guava EasyCyte Plus (Millipore). To determine whether SPP1, produced by the steroidogenic cells, stimulates T-cell proliferation, luteal cells and $\mathrm{T}$ cells were transfected separately with either lentiviral particles directed toward
SPP1 mRNA or scrambled sequence control and then proliferation was analyzed after $24 \mathrm{~h}$ using Guava EasyCyte Plus (Millipore).

\section{Lymphocyte chemotaxis assay}

Lymphocyte migration was measured using QCM chemotaxis 96-well plates fitted with $3 \mu \mathrm{m}$ membrane inserts (Millipore) according to the manufacturer's instructions. Lymphocytes were placed in the upper chamber of a QCM apparatus and luteal cells and/or increasing concentrations of SPP1 (Sigma-Aldrich) were placed in the lower chamber of the QCM apparatus. To determine the role of SPP1 in luteal cell-induced T-cell chemotaxis, luteal cells and $\mathrm{T}$ cells were transfected separately with either lentiviral particles directed toward SPP1 mRNA or scrambled sequence control prior to coculture in the QCM apparatus. Increasing concentrations of monocyte chemoattractant protein 1 (CCL2) were used as a positive control for lymphocyte migration (Carr et al. 1994). After $24 \mathrm{~h}$ of incubation at $37^{\circ} \mathrm{C}$, $\mathrm{T}$ cells that migrated toward the chemoattractant were recovered from the lower chamber and unmigrated $\mathrm{T}$ cells from the inserts according to the manufacturer's instructions. Migrated T cells were stained with a green fluorescent dye (CyQuant GR dye, Millipore) and then transferred to a 96-well flat-bottomed ELISA microplate (Costar) and fluorescence was read at $485 / 535 \mathrm{~nm}$ using Wallac 1420 fluorescent plate reader (Perkin Elmer, Waltham, MA, USA). Data are reported in fluorescent units representing $\mathrm{T}$ cells that migrated into the lower chamber toward chemoattractant.

\section{Flow cytometry}

Lymphocytes were prepared for dual-color flow cytometric analysis by indirect immunofluorescence following luteal cell and T-cell coculture. Lymphocytes were diluted to $5.0 \times 10^{5}$ cells $/ \mathrm{ml}$ and antibody incubations and washes were performed at $4{ }^{\circ} \mathrm{C}$ as described previously (Davis \& Pate 2007). $\mathrm{T}$ cells were incubated with mouse anti-bovine $\gamma \delta$ (CACT61A), mouse anti-bovine CD8 $\alpha$ (CACT80C or BAQ111A), and mouse anti-bovine CD8 $\beta$ (BAT82A) for $30 \mathrm{~min}$, washed, and incubated for 30 min with the appropriate secondary antibodies. Rabbit anti-mouse IgM conjugated to FITC (102002) was used to detect $\gamma \delta$ or CD $8 \alpha$ T cells; rabbit anti-mouse IgG1 conjugated to RPE (STAR81PE) was used to detect CD8 $\alpha$ 
or CD8 $\beta$ T cells. Prior to analysis, lymphocytes were resuspended in ice-cold PBS $+2 \mathrm{mM}$ EDTA to an optimal running concentration of $\leq 500$ cells/ $\mu$ l and analyzed by flow cytometry. Unlabeled $\mathrm{T}$ lymphocytes, $\mathrm{T}$ lymphocytes labeled only with secondary antibodies, and $\mathrm{T}$ lymphocytes labeled with isotype-matched antibody were used to determine autofluorescence and nonspecific binding. A total of 10000 $\mathrm{T}$ lymphocytes were analyzed for each sample.

\section{Statistical analysis}

All statistical analyses were performed using the mixed model of SAS (Statistical Analysis System Institute, Cary, NC, USA). Gene expression data were log-transformed and analyzed using covariate analysis, with GAPDH as the covariate. Two-way ANOVA followed by the Student-Newman-Keuls test was performed to determine differences among treatment groups for lymphocyte proliferation, chemotaxis, and functional phenotypes. All experiments were repeated with CL from three to five separate animals and data are presented as least-square means \pm s.E.M. Differences were considered significant at $P<0.05$.

\section{Results}

Expression of SPP1 was significantly less in day $4 \mathrm{CL}$ compared with CL collected on days 5, 10, and 18 of the estrous cycle, but there were no differences in SPP1 mRNA among $\mathrm{CL}$ from days 5, 10, and $18(P>0.05$; Fig. 1A). The concentration of SPP1 mRNA significantly increased in the CL within $1 \mathrm{~h}$ following a luteolytic dose of $\mathrm{PGF}_{2 \alpha}$ and was further elevated by 4 and $8 \mathrm{~h}$ after $\mathrm{PGF}_{2 \alpha}(P<0.05$; Fig. 1B). Specific bands of the expected molecular size corresponding to the full-length bovine SPP1 protein $(70 \mathrm{kDa})$ and the cleaved, active isoform
(45 kDa) were detected in $\mathrm{CL}$ throughout the estrous cycle and after PGF $_{2 \alpha}$ (Fig. 1C and D). An additional $25 \mathrm{kDa}$ cleavage product of SPP1 was observed in developing (day 5) and late cycle (day 18) CL, but this form of SPP1 was completely absent in the fully functional (day 10) CL (Fig. 1C). The day 18 sample shown in Fig. 1D had a low concentration of SPP1 overall, making the $25 \mathrm{kDa}$ band undetectable, which was not representative of the other day 18 samples shown in Fig. 1C. Immunohistochemical localization revealed the presence of SPP1 in small and large steroidogenic cells as well as scattered immune cells in early (day 5, Fig. 2A), fully functional (day 10), and late cycle (day 18) CL (not shown). In addition, SPP1 was identified in large luteal cells and infiltrating immune cells at 2, 4, and $8 \mathrm{~h}$ after $\mathrm{PGF}_{2 \alpha}$ (Fig. 2B).

There was a slight but significant increase in the expression of the mRNA for the SPP1 receptor, hyaluronic acid receptor (CD44), which paralleled the increase in SPP1 from day 4 to day $5 \mathrm{CL}$, and remained elevated through day $18(P<0.05$; Fig. 3A). However, $C D 44 \mathrm{mRNA}$ did not change during luteal regression $(P>0.05$; Fig. 3B). $\beta 3$ integrin (ITGB3), which has been shown to colocalize with SPP1 in other reproductive tissues, was expressed in the bovine $\mathrm{CL}$ but remained unchanged throughout the estrous cycle $(P>0.05$; Fig. 3A). However, the induction of luteolysis with $\mathrm{PGF}_{2 \alpha}$ resulted in a decrease in ITGB3 mRNA at 4 and $8 \mathrm{~h}$ compared with control $(0 \mathrm{~h} ; P<0.05$; Fig. $3 \mathrm{~B})$. Expression of interleukin 10 (IL 10) and IL12A mRNA in luteal tissue was significantly greater on days 5 and 10 compared with day 4 ( $P<0.05$; Fig. 3C), paralleling the changes in SPP1 and its receptors. Both IL 10 and IL $12 A$ declined between days 10 and 18 ( $P<0.05$; Fig. 3C).
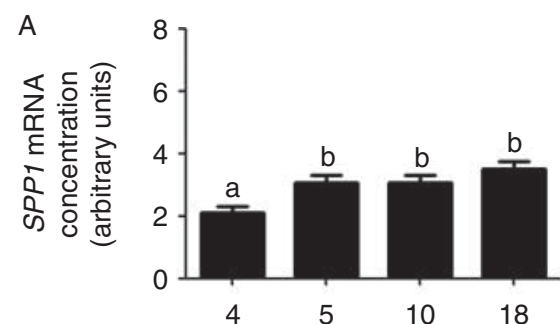

Day of the estreous cycle

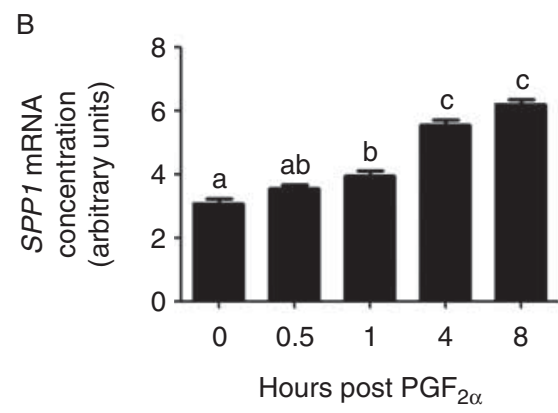

35

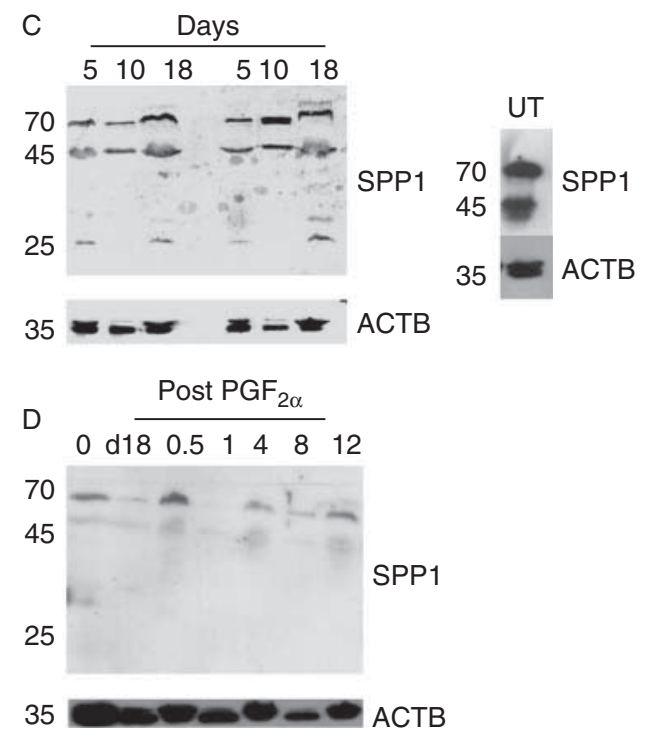

Figure 1 Steady-state concentrations of mRNA encoding SPP1 in CL during the estrous cycle $(\mathrm{A} ; n=4)$ and after $\mathrm{PGF}_{2 \alpha}$ injection $(\mathrm{B} ; n=4)$. Bars represent logtransformed least-squared mean values \pm S.E.M. Different letters indicate significant differences $(P<0.05)$. Representative western blots of bovine luteal tissue using antibodies against SPP1 during different functional stages of the estrous cycle (developing (day 5), fully functional (day 10), and late cycle (day 18) and at specific times after $\mathrm{PGF}_{2 \alpha}$ injection; $\mathrm{C}$ and $\left.\mathrm{D}\right)$. This experiment was repeated four times and proteins isolated from bovine uterus (UT) served as a positive control. 


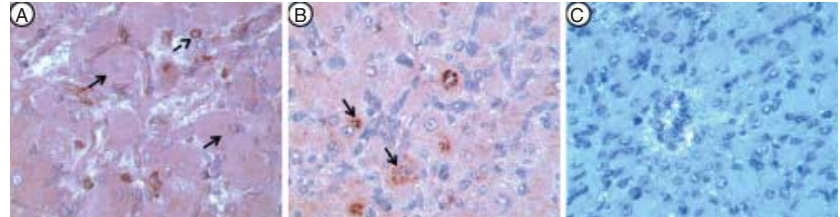

Figure 2 Immunohistochemical localization of SPP1 in developing CL (A; day 5 ) and $8 \mathrm{~h}$ after $\mathrm{PGF}_{2 \alpha}$ (B). Solid arrows and diffuse brown staining indicate the presence of SPP1 in large and small steroidogenic cells. More intense staining was observed in scattered small cells that are likely immune cells (dashed arrows). No staining was observed in the IgG-negative control (C). Images presented are representative of four $\mathrm{CL}$ per time point examined taken at $400 \times$ magnification.

IL10, but not IL12A, mRNA was reduced at 1 and $8 \mathrm{~h}$ after $\mathrm{PGF}_{2 \alpha}(P<0.05$; Fig. 3D).

Luteal cells were cultured with factors known to regulate luteal function to evaluate their effect on SPP1 production. The addition of $\mathrm{LH}, \mathrm{P}_{4}$, and/or AG (to inhibit $\mathrm{P}_{4}$ production) had no effect on SPP1 mRNA in cultured luteal cells $(P>0.05$; Fig. 4A). However, the addition of $\mathrm{PGF}_{2 \alpha}$ and/or TNF significantly increased SPP1 mRNA $(P<0.05$; Fig. 4B and $\mathrm{C})$. Western blot analysis revealed specific bands of the 45 and $70 \mathrm{kDa}$ forms of SPP1 in all cultured luteal cells treated with $\mathrm{LH}, \mathrm{P}_{4}, \mathrm{PGF}_{2 \alpha}$, and TNF, alone or in combination with LH (Fig. 4D).

To determine whether SPP1 is involved in luteal cell-T-cell communication, luteal cells and T lymphocytes were cultured for $24 \mathrm{~h}$ with increasing concentrations (12 500, 25 000, or 37500 IFU/ $\mu$ l) of viral IFU containing either SPP1 siRNA or scrambled sequence controls. Immunoblots for SPP1 revealed that the active isoform (45 kDa) of SPP1 in both luteal cells and lymphocytes decreased as viral particle concentration increased (Fig. 5A and B). Ablation and replacement studies were conducted to determine the effects of SPP1 on luteal cell-induced T-cell proliferation, chemotaxis, and cellular function. Luteal cells stimulated lymphocyte proliferation in vitro, regardless of treatment $(P<0.05$; Fig. 5C). Neither a reduction of endogenous nor addition of exogenous SPP1 altered luteal cell-stimulated lymphocyte proliferation ( $P>0.05$; Fig. 5C). In lymphocyte-only cultures, knockdown of SPP1 did not alter lymphocyte migration compared with control lymphocytes $(P>0.05 ;$ Fig. 5D). However, lymphocyte migration was stimulated by luteal cells $(P<0.05$; Fig. 5D) and lymphocyte chemotaxis toward luteal cells was decreased when SPP1 was reduced $(P<0.05$; Fig. 5D). However, the addition of exogenous SPP1 did not increase T-cell migration (Fig. 5D). Moreover, luteal cells were capable of inducing even greater lymphocyte migration than CCL2.

Treatment with SPP1 siRNA or scrambled sequence control siRNA in the lentiviral vector increased the proportion of $\gamma \delta^{+}$and $\gamma \delta^{+} \mathrm{CD}^{+}$lymphocytes $(P<0.05$; Fig. 6A and B). However, this effect was diminished in the presence of luteal cells $(P<0.05$;
Fig. 6B). In addition, the number of CD8 $\alpha \alpha^{+} \mathrm{T}$ cells increased when $T$ cells, cultured alone or with luteal cells, were treated with either the SPP1 siRNA or the scrambled sequence control siRNA $(P<0.05$; Fig. 7A). The shift in CD8 $\alpha \alpha^{+} \mathrm{T}$ cells resulted in a small reduction in the number of $\mathrm{CD} 8 \alpha \beta^{+} \mathrm{T}$ cells when cultured alone, but not when $\mathrm{T}$ cells were cultured with luteal cells $(P<0.05$; Fig. 7A).

\section{Discussion}

Following ovulation, the theca and granulosa cells of the ovulated follicle undergo extensive tissue remodeling and differentiation to form the CL. Silvester \& Luck (1999) proposed that luteinization may be best understood as a wound repair-like process. SPP1 has an important role in cell-to-cell and cell-to-extracellular matrix signaling (Giachelli \& Steitz 2000) and can be expected to be highly expressed in tissues undergoing extensive structural development such as during formation of the CL. SPP1 and thrombin colocalize in highly vascularized areas, including sites of tissue damage, such as in wounds, tumors, and at sites of inflammation (Dvorak 1986). Cleavage of the full-length SPP1 protein by thrombin and/or other proteases exposes the glycinearginine-glycine-aspartic acid-serine (GRGDS) region of the protein, which is critical for proper binding to its receptors and mediating cell-to-cell and cell-to-extracellular matrix interactions (Senger et al. 1994, Denhardt \& Noda 1998). Gabler et al. (2003) identified three SPP1 products of different molecular mass $(55,48$, and $25 \mathrm{kDa}$ ) in bovine oviductal fluid. In addition, Johnson et al. (1999) reported a similar pattern of three SPP1 products $(70,45$, and $25 \mathrm{kDa})$ in ovine endometrial
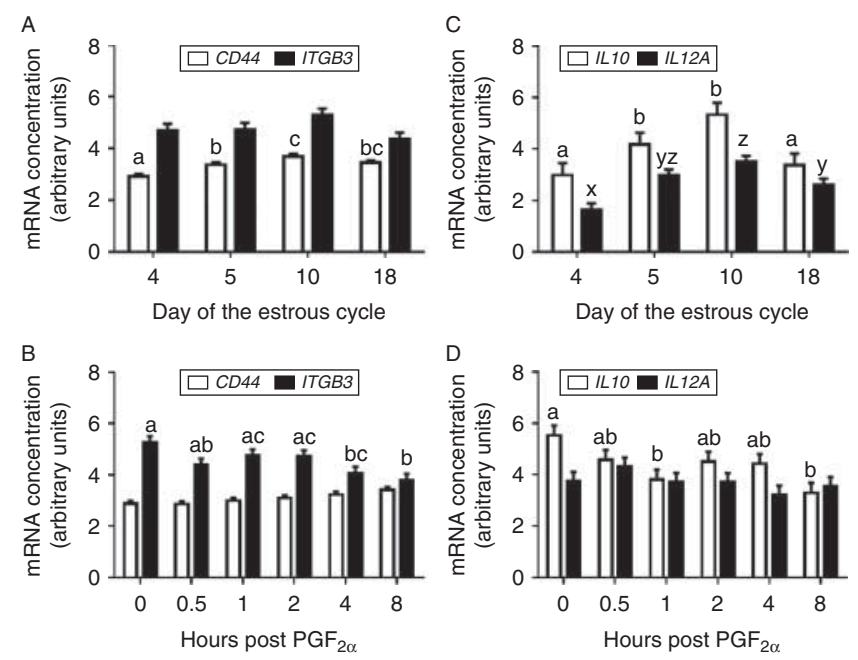

Figure 3 Steady-state concentrations of $\mathrm{mRNA}$ encoding CD44 ( $\mathrm{A}$ and $\mathrm{B}$; open bars), integrin $\beta 3$ (ITGB3; $\mathrm{A}$ and $\mathrm{B}$; solid bars), IL 10 (C and D; open bars), and IL12A (C and D; solid bars) in CL during the estrous cycle ( $\mathrm{A}$ and $\mathrm{C} ; n=4$ ) or luteal regression ( $\mathrm{B}$ and $\mathrm{D}$; $n=4)$. Bars represent log-transformed least-squared mean values. Different letters indicate significant differences $(P<0.05)$. 

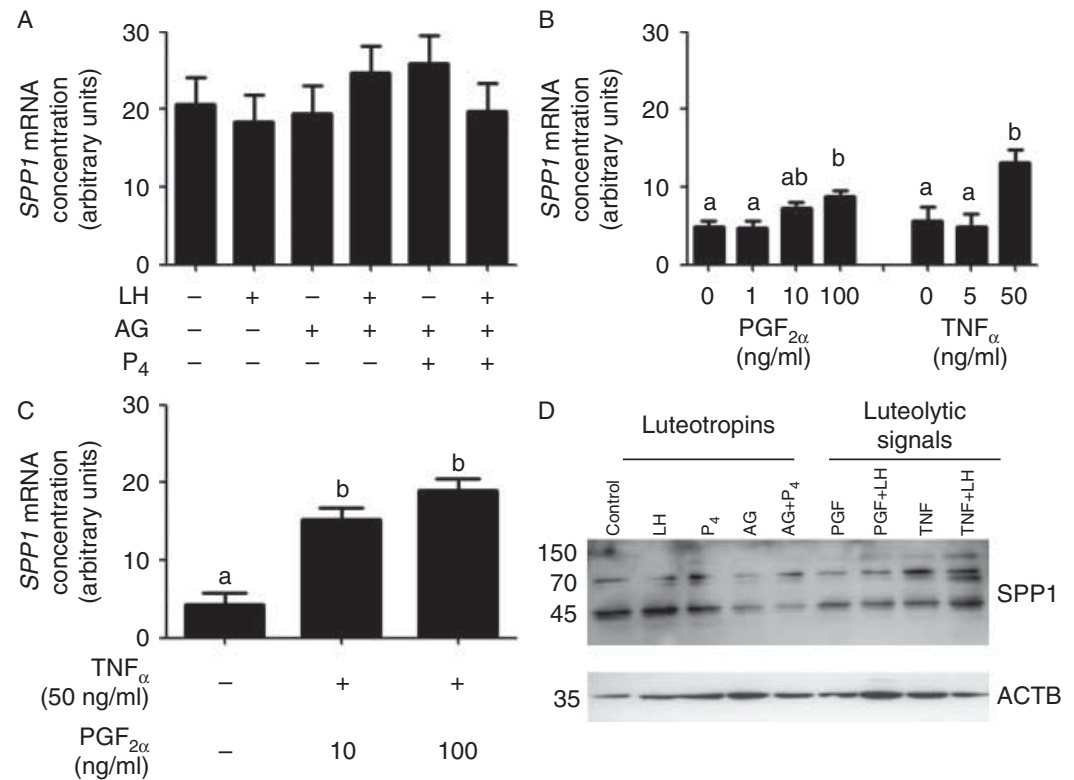

Figure 4 Steady-state concentrations of mRNA encoding SPP1 in bovine luteal cells following treatment with $\mathrm{LH}(50 \mathrm{ng} / \mathrm{ml}), \mathrm{AG}(50 \mathrm{ng} / \mathrm{ml})$, and $\mathrm{P}_{4}(0.5 \mu \mathrm{M} ; \mathrm{A} ; n=4)$. Effect of $\mathrm{PGF}_{2 \alpha}$ and TNF separately (B) and in combination (C) on the steady-state concentration of SPP1 mRNA $(n=4)$. Bars represent log-transformed least squared mean values and different letters indicate significant differences $(P<0.05)$. Representative western blot for SPP1 in cultured bovine luteal cells (D). Treatments consisted of $\mathrm{LH}, \mathrm{P}_{4}, \mathrm{AG}, \mathrm{P}_{4},+\mathrm{AG}, \mathrm{PGF}_{2 \alpha}$ $\mathrm{PGF}_{2 \alpha}+\mathrm{LH}, \mathrm{TNF}$, and TNF $+\mathrm{LH}$ or no treatment (control, lane 1). extracts. The SPP1 protein contains a thrombin cleavage site region (Senger et al. 1994, Denhardt \& Noda 1998) and when cleaved results in a 23-25 kDa cleavage product (Zhang et al. 1990). Western blot analyses demonstrated that the full-length $(70 \mathrm{kDa})$ and the cleaved, activated (45 kDa) isoform of bovine SPP1 are present in $\mathrm{CL}$ throughout the estrous cycle. However, the presence of a $25 \mathrm{kDa}$ cleavage product of SPP1 was also observed in developing and late cycle $\mathrm{CL}$, which suggests a potential role of SPP1 signaling during periods of luteal tissue remodeling.

Craig \& Denhardt (1991) first demonstrated that sex steroids, primarily $\mathrm{P}_{4}$, upregulated Spp1 mRNA in the mouse endometrium. Moreover, SPP1 expression was greatest $6 \mathrm{~h}$ after treatment with $\mathrm{P}_{4}$ but expression was diminished by $24 \mathrm{~h}$ after treatment (Craig \& Denhardt 1991). In addition, $P_{4}$ stimulated SPP1 expression in the developing ovine uterine glandular epithelium during the peri-implantation period (Johnson et al. 2000). $P_{4}$ stimulates hypertrophy and hyperplasia of the glandular epithelium and development of the uterine glands to produce numerous growth factors, in addition to SPP1, to provide hematotrophic nutrition to the conceptus (Gray et al. 2002). Johnson et al. (2000) suggested that $\mathrm{P}_{4}$ upregulation of SPP1 expression within the uterus may be mediated through additional paracrine factors, such as placental lactogen. Dunlap et al. (2008) concluded that placental factors, including placental
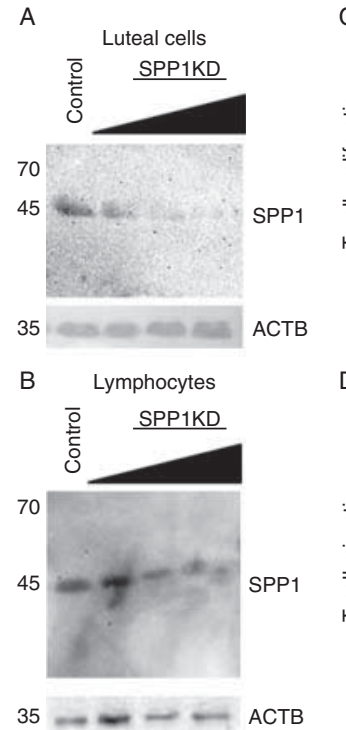

www.reproduction-online.org
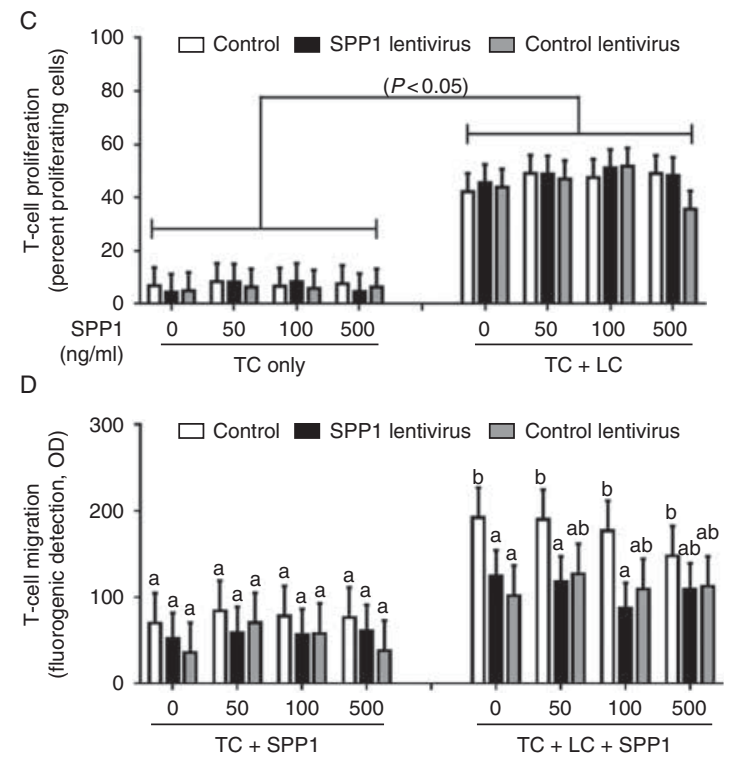

Figure $\mathbf{5}$ Luteal cells and T lymphocytes were cultured for $24 \mathrm{~h}$ with increasing concentrations of viral IFU containing either SPP1 siRNA or scrambled sequence controls (lane $1=12$ 500; lane $2=25$ 000; and lane $3=37500 \mathrm{IFU} / \mu \mathrm{l}$ ). Representative western blot analyses using antibodies against SPP1 for protein expression in bovine luteal cells (A) and lymphocytes (B) display effective knockdown of endogenous SPP1. Luteal cells (LC) and lymphocytes (TC) were treated with lentiviral particles, either directed against SPP1 mRNA (black bars) or scrambled sequence control (gray bars) or no lentiviral particles (control; white bars) prior to culture. Following SPP1 knockdown, lymphocytes were then placed in culture for $24 \mathrm{~h}$ with increasing concentrations of SPP1 (0, 50, 100, or $500 \mathrm{ng} / \mathrm{ml}$ ) or in coculture with LC and increasing concentrations of SPP1 $(0,50,100$, or $500 \mathrm{ng} / \mathrm{ml})$ to evaluate the effect of SPP1 on T-cell proliferation (C) or chemotaxis (D). Bars represent least-squared mean values $(n=4)$ and different letters indicate significant differences $(P<0.05)$. 

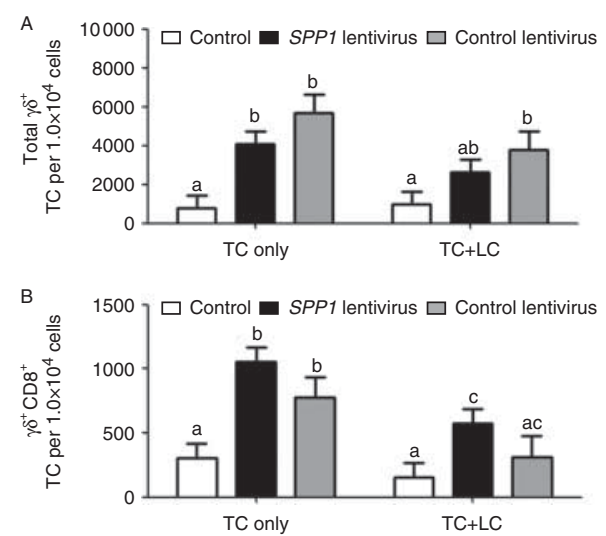

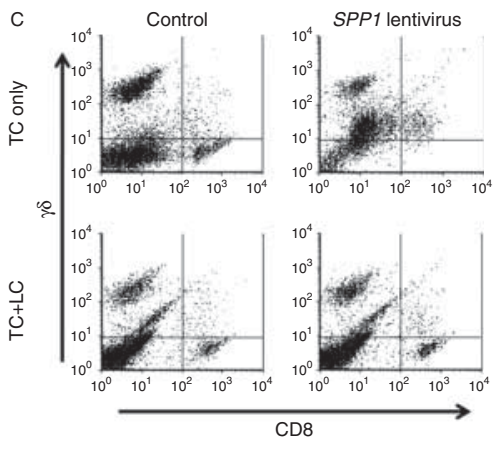

Figure $6 \mathrm{~T}$ cells $(\mathrm{TC})$ were treated with lentiviral particles, either directed against SPP1 mRNA (black bars) or scrambled sequence control (gray bars) or no lentiviral particles (control; white bars) prior to culture. The proportions of total gamma delta $\left(\gamma \delta^{+} \mathrm{CD}^{+/-} ; \mathrm{A}\right)$ and $\gamma \delta^{+} \mathrm{CD}^{+}(\mathrm{B})$ $\mathrm{TC}$ either cultured alone (TC only) or in the presence of luteal cells $(\mathrm{TC}+\mathrm{LC})$ are depicted. Bars represent least-squared mean values and different letters indicate significant differences $(P<0.05, n=4)$. Representative scatter diagrams of control and SPP1 lentiviral-treated lymphocytes dual-labeled for $\gamma \delta$ and $\mathrm{CD}^{+}(\mathrm{C})$.

lactogen, increase glandular epithelium hyperplasia, which lead to increased SPP1 gene expression in addition to $\mathrm{P}_{4}$ alone. In the current study, the increase in SPP1 expression following $\mathrm{P}_{4}$ treatment was not observed in luteal cells. This response could be attributed to either the length of $\mathrm{P}_{4}$ exposure or the absence in our cultures of additional paracrine factors that would have been present within the uterus.

In cattle, the $\mathrm{CL}$ is resistant to the luteolytic effects of $\mathrm{PGF}_{2 \alpha}$ before day 5 of the estrous cycle (Rowson et al. 1972), and therefore the $C L$ must acquire the capacity to regress in response to $\mathrm{PGF}_{2 \alpha}$ (luteolytic capacity; Tsai \& Wiltbank (1998)). Several factors including endothelin 1 (EDN1, Wright et al. 2001), CCL2 (Townson et al. 2002), and 15-hydroxyprostaglandin dehydrogenase (Silva et al. 2000) have been proposed mediators for acquisition of luteolysis. Increases in these factors were observed in fully functional (day 10) CL when compared with early (day 4) $\mathrm{CL}$, thus suggesting their role in acquisition of luteolytic capacity. In the current study, there was a significant increase in SPP1 mRNA during this transition period between days 4 and 5 of the estrous cycle, which is the time during which $\mathrm{CL}$ begin to acquire luteolytic capacity (Tsai \& Wiltbank 1998). It is suggested that the increase in SPP1 in day 5 CL facilitates luteal sensitivity to $\mathrm{PGF}_{2 \alpha}$ and luteolytic capacity.

In addition to the changes in SPP1 expression early in the estrous cycle, there was an immediate increase in SPP1 mRNA within $1 \mathrm{~h}$ of a luteolytic injection of $\mathrm{PGF}_{2 \alpha}$. Furthermore, SPP1 expression continued to increase 4 and $8 \mathrm{~h}$ after $\mathrm{PGF}_{2 \alpha}$. In vitro experiments demonstrated that two luteolytic factors, $\mathrm{PGF}_{2 \alpha}$ and TNF, increased SPP1 expression in cultured luteal cells. The upregulation of SPP1 during luteolysis may serve as a signaling molecule to recruit immune cells into the $\mathrm{CL}$ to facilitate luteal regression and tissue degradation.

Two types of receptors have been shown to mediate SPP1 actions. First, SPP1 can bind to integrins via interaction with the GRGDS region of the protein (Denhardt \& Noda 1998). Johnson et al. (2001) demonstrated that $\alpha_{v} \beta_{3}, \alpha_{v} \beta_{1}, \alpha_{v} \beta_{5}, \alpha_{4} \beta_{1}$, and $\alpha_{5} \beta_{1}$ integrin heterodimers serve as SPP1 receptors in the ovine uterus to initiate outside-in signaling and mediate attachment of the conceptus. Alternatively, SPP1 can also bind to CD44, the hyaluronic acid receptor, to activate immune cell responses (Weber et al. 1996).
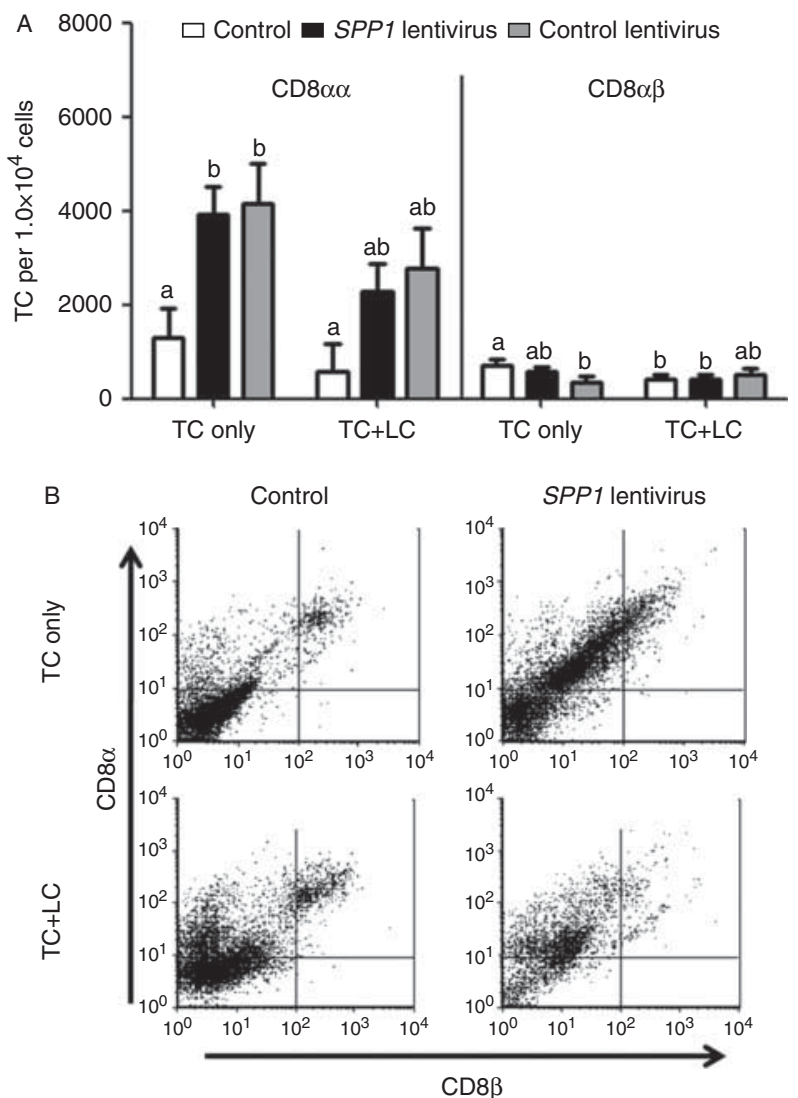

Figure 7 (A) T cells (TC) were treated with lentiviral particles, either directed against SPP1 mRNA (black bars) or scrambled sequence control (gray bars) or no lentiviral particles (control; white bars) prior to culture. The proportions of CD $8 \alpha \alpha^{+}$and CD $8 \alpha \beta^{+} \mathrm{TC}$ either cultured alone (TC only) or in the presence of luteal cells $(\mathrm{TC}+\mathrm{LC})$ are depicted. Bars represent least-squared mean values and different letters indicate significant differences $(P<0.05, n=4)$. Representative scatter diagrams of control and SPP1 lentiviral-treated lymphocytes dual-labeled for $\mathrm{CD} 8 \alpha$ and $\mathrm{CD} 8 \beta(\mathrm{B})$. 
In this study, there was a decrease in ITGB3 mRNA, but not CD44 mRNA, in luteal tissue following a luteolytic dose of $\mathrm{PGF}_{2 \alpha}$. The loss of ITGB3 following PGF $2 \alpha$ could be associated with the degradation of the extracellular matrix and altered cellular environment that occurs during luteal regression as reported by Smith et al. (1999). In the CL, expression of CD44 mRNA paralleled SPP1 mRNA throughout the estrous cycle whereas ITGB3 mRNA remained unchanged. The cell surface glycoprotein, CD44, is expressed in many cell types, including leukocytes, erythrocytes, fibroblasts, endothelial and epithelial cells, and a variety of tumor cells (Lesley et al. 1993) and is responsible for many cellular responses including cell-to-cell and cell-to-ECM interactions and stimulation of immune cells (reviewed by Cichy \& Puré (2003)). Activation of macrophage surface CD44 via antibody stimulation resulted in increased phagocytosis of apoptotic neutrophils in vitro (Vivers et al. 2004). Within the pig ovary, Miyake et al. (2006) examined the role of CD44 in ovarian macrophages and concluded that CD44 may be responsible for removing apoptotic granulosa cells in atretic follicles. Binding of SPP1 to its receptors influences cytokine production (O'Regan et al. 1999, O'Regan \& Berman 2000). Ashkar et al. (2000) demonstrated that SPP1 increased IL12 and suppressed IL10 production by macrophages, acting through $\alpha_{v} \beta_{3}$ and CD44 receptors respectively. Thus, the effect of SPP1 on the IL10:IL12 ratio may depend on the relative abundance of these two receptors. In the current study, both IL10 and IL12A mRNA increase in the developing $C L$ reaching maximal expression in the fully functional CL. The expression of the mRNA for the anti-inflammatory cytokine, IL10, was greater than that for the proinflammatory cytokine, IL12. If protein concentrations (not quantified in this study) are reflective of differences in IL1O/IL12 mRNA concentrations, it would suggest that the developing $\mathrm{CL}$ establishes a microenvironment suitable to ensure luteal homeostasis. During luteolysis, reduced ITGB3 and IL 10 would allow for a proinflammatory environment, leading to destruction of the tissue and leukocyte chemotaxis.

Functional interactions exist between $\mathrm{T}$ cells and luteal cells in vitro including luteal cell induction of T-cell proliferation and inhibition of steroidogenesis by immune cell-derived proinflammatory cytokines (reviewed by Pate \& Keyes (2001)). Patarca et al. (1989) demonstrated that SPP1 stimulated lymphocyte activation at the initiation of an immune response. Thus, the increase in luteal SPP1 in response to $\mathrm{PGF}_{2 \alpha}$ both in vitro and in vivo could serve as a signaling molecule to modulate lymphocyte function in the regressing $\mathrm{CL}$, but based on the current results, any such response is not likely to involve T-cell proliferation.

The addition of exogenous SPP1 had no effect on lymphocyte chemotaxis, possibly because it dispersed throughout the media, failing to create a desirable concentration gradient or because the SPP1 was not cleaved into bioactive fragments (Senger et al. 1994). Regardless, knockdown of SPP1 reduced luteal cell-induced lymphocyte migration and removing SPP1 from the culture system significantly reduced T-cell migration, providing support for the hypothesis that SPP1 serves as a lymphocyte chemoattractant within the $C L$ during periods of luteal tissue remodeling. A similar role for SPP1 was reported by Cheng et al. (2007).

Lentiviral vectors can provide an effective means for gene transfer into human lymphocytes without T-cell activation, thus preserving the phenotype and functional characteristics of the transduced T cells (Cavalieri et al. 2003). However, lentiviral particles containing either SPP1 or scrambled sequence siRNA increased the proportion of total $\gamma \delta^{+}, \gamma \delta^{+} \mathrm{CD}^{+}$, and $\mathrm{CD} 8 \alpha \alpha^{+}$ lymphocytes and decreased the proportion of $C D 8 \alpha \beta^{+}$ lymphocytes in this study. The vast majority of peripheral blood lymphocytes of humans and mice express the $\alpha \beta$ TCR, whereas lymphocytes expressing the $\gamma \delta$ TCR are prominent in peripheral blood of ruminants (Mackay \& Hein 1989). Unlike the $\alpha \beta$ T cells, $\gamma \delta$ T cells recognize, but are not restricted to, class I and II MHC molecules and have been shown to respond to a wide range of molecules (reviewed by Chien et al. (1996)). Gamma delta T cells are capable of killing virus-infected cells in vitro (Bukowski et al. 1994) and are activated in response to viral infections in vivo (De Paoli et al. 1990, Wallace et al. 1995), which likely explains the results obtained in this study in response to lentiviral particles.

During times of tissue remodeling, such as during luteal development and luteolysis, SPP1 facilitates recruitment and/or activation of immune cells and SPP1 may influence the responsiveness of the $\mathrm{CL}$ to the luteolytic effects of $\mathrm{PGF}_{2 \alpha}$. The increase in SPP1 mRNA between day 4 and 5 of the estrous cycle may be essential for proper luteal development and sensitivity to the luteolytic effects of $\mathrm{PGF}_{2 \alpha}$. Furthermore, inhibition of endogenous SPP1 reduced luteal cell-induced lymphocyte chemotaxis, and there was an increase in luteal SPP1 in response to $\mathrm{PGF}_{2 \alpha}$ both in vitro and in vivo, providing evidence that SPP1 plays an active role as a signaling molecule to recruit lymphocytes into the regressing $\mathrm{CL}$. Based on these data, it is concluded that this diverse protein is initially upregulated, allowing for acquisition of luteolytic capacity in the developing CL. Additionally, SPP1 increases during luteolysis, to serve as a signaling molecule to recruit immune cells into the $\mathrm{CL}$ to facilitate luteal regression and tissue degradation.

\section{Declaration of interest}

The authors declare that there is no conflict of interest that could be perceived as prejudicing the impartiality of the research reported. 


\section{Funding}

This work was supported by National Research Initiative Competitive grant number 2008-35203-04617 from the USDA National Institute of Food and Agriculture to J L Pate.

\section{Acknowledgements}

The authors wish to thank Jodi Winkler, Justin Fear, Sadhat Walusimbi, and Edyta Brzezicka for their assistance with sample and PCR data collection and Dr Gary Killian for his generous donation of bovine SPP1 antibody.

\section{References}

Ashkar S, Weber GF, Panoutsakopoulou V, Sanchirico ME, Jansson M, Zawaideh S, Rittling SR, Denhardt DT, Glimcher MJ \& Cantor H 2000 SPP1 (osteopontin): an early component of type-1 (cell-mediated) immunity. Science 287 860-864. (doi:10.1126/science.287.5454.860)

Asou Y, Rittling SR, Yoshitake H, Tsuji K, Shinomiya K, Nifuji A, Denhardt DT \& Noda M 2001 Osteopontin facilitates angiogenesis, accumulation of osteoclasts, and resorption in ectopic bone. Endocrinology 142 1325-1332. (doi:10.1210/en.142.3.1325)

Benyo DF \& Pate JL 1992 Tumor necrosis factor- $\alpha$ alters bovine luteal cell synthetic capacity and viability. Endocrinology 130 854-860. (doi:10.1210/en.130.2.854)

Bove SE, Petroff MG, Nishibori M \& Pate JL 2000 Macrophage migration inhibitory factor in the bovine corpus luteum: characterization of steady-state messenger ribonucleic acid and immunohistochemical localization. Biology of Reproduction 62 857-885. (doi:10.1095/ biolreprod62.4.879)

Bradford MM 1976 A rapid and sensitive method for the quantitation of microgram quantities of protein utilizing the principle of protein-dye binding. Analytical Biochemistry 72 248-254. (doi:10.1016/00032697(76)90527-3)

Brännström M \& Norman RJ 1993 Involvement of leukocytes and cytokines in the ovulatory process and corpus luteum function. Human Reproduction 8 1762-1775.

Brown LF, Berse B, Van de Water L, Papadopoulos-Sergiou A, Perruzzi CA, Manseau EJ, Dvorak HF \& Senger DR 1992 Expression and distribution of osteopontin in human tissues: widespread association with luminal epithelial surfaces. Molecular Biology of the Cell 3 1169-1180. (doi:10.1091/mbc.3.10.1169)

Brunswig-Spickenheier B \& Mukhopadhyay AK 2003 Expression of osteopontin (OPN) mRNA in bovine ovarian follicles and corpora lutea. Reproduction in Domestic Animals 38 175-181. (doi:10.1046/ j.1439-0531.2003.00413.x)

Bukowski JF, Morita CT \& Brenner MB 1994 Recognition and destruction of virus-infected cells by human gamma delta CTL. Journal of Immunology 153 5133-5140.

Carr MW, Roth SJ, Luther E, Rose SS \& Springer TA 1994 Monocyte chemoattractant protein 1 acts as a T-lymphocyte chemoattractant. PNAS 91 3652-3656. (doi:10.1073/pnas.91.9.3652)

Cavalieri S, Cazzaniga S, Geuna M, Magnani Z, Bordignon C, Naldini L \& Bonini C 2003 Human T lymphocytes transduced by lentiviral vectors in the absence of TCR activation maintain an intact immune competence. Blood 102 497-505. (doi:10.1182/blood-2003-01-0297)

Cheng J, Huo DH, Kuang DM, Yang J, Zheng L \& Zhuang SM 2007 Human macrophages promote the motility and invasiveness of osteopontinknockdown tumor cells. Cancer Research 67 5141-5147. (doi:10.1158/ 0008-5472.CAN-06-4763)

Chien YH, Jores R \& Crowley MP 1996 Recognition by gamma/delta T cells. Annual Reviews in Immunology 14 511-532. (doi:10.1146/annurev. immunol.14.1.511)

Cichy J \& Puré E 2003 The liberation of CD44. Journal of Cell Biology 161 839-843. Review. (doi:10.1083/jcb.200302098)
Craig AM \& Denhardt DT 1991 The murine gene encoding secreted phosphoprotein 1 (osteopontin): promoter structure, activity, and induction in vivo by estrogen and progesterone. Gene 100 163-171. (doi:10.1016/0378-1119(91)90362-F)

Davis TL \& Pate JL 2007 Bovine luteal cells stimulate proliferation of major histocompatibility nonrestricted gamma delta T cells. Biology of Reproduction 77 914-922. (doi:10.1095/biolreprod.106.059824)

Denhardt DT \& Noda M 1998 Osteopontin expression and function: role in bone remodeling. Journal of Cellular Biochemistry. Supplement 30-31 92-102. (doi:10.1002/(SICl)1097-4644(1998)72:30/31+<92::AIDJCB13>3.0.CO;2-A)

Denhardt DT, Giachelli CM \& Rittling SR 2001 Role of osteopontin in cellular signaling and toxicant injury. Annual Review of Pharmacology and Toxicology 41 723-749. (doi:10.1146/annurev.pharmtox.41.1.723)

De Paoli P, Gennari D, Martelli P, Cavarzerani V, Comoretto R \& Santini G $1990 \gamma \delta$ T cell receptor-bearing lymphocytes during Epstein-Barr virus infection. Journal of Infectious Diseases 161 1013-1016. (doi:10.1093/ infdis/161.5.1013)

Dunlap KA, Erikson DW, Burghardt RC, White FJ, Reed KM, Farmer JL, Spencer TE, Magness RR, Bazer FW, Bayless KJ et al. 2008 Progesterone and placentation increase secreted phosphoprotein one (SPP1 or osteopontin) in uterine glands and stroma for histotrophic and hematotrophic support of ovine pregnancy. Biology of Reproduction 79 983-990. (doi:10.1095/biolreprod.108.071068)

Dvorak HF 1986 Tumors: wounds that do not heal. Similarities between tumor stroma generation and wound healing. New England Journal of Medicine 315 1650-1659. (doi:10.1056/NEJM198612253152606)

Erikson DW, Burghardt RC, Bayless KJ \& Johnson GA 2009 Secreted phosphoprotein 1 (SPP1, osteopontin) binds to integrin alpha $v$ beta 6 on porcine trophectoderm cells and integrin alpha $v$ beta 3 on uterine luminal epithelial cells, and promotes trophectoderm cell adhesion and migration. Biology of Reproduction 81 814-825. (doi:10.1095/biolreprod.109.078600)

Franzen A \& Heinegard D 1985 Isolation and characterization of two sialoproteins present only in bone calcified matrix. Biochemical Journal 232 715-724.

Gabler C, Chapman DA \& Killian GJ 2003 Expression and presence of osteopontin and integrins in the bovine oviduct during the estrous cycle. Reproduction 126 721-729. (doi:10.1530/rep.0.1260721)

Giachelli CM \& Steitz S 2000 Osteopontin: a versatile regulator of inflammation and biomineralization. Matrix Biology 19 615-622. (doi:10.1016/S0945-053X(00)00108-6)

Gray CA, Burghardt RC, Johnson GA, Bazer FW \& Spencer TE 2002 Evidence that absence of endometrial gland secretions in uterine gland knockout ewes compromises conceptus survival and elongation. Reproduction 124 289-300. (doi:10.1530/rep.0.1240289)

Hirama M, Takahashi F, Takahashi K, Akutagawa S, Shimizu K, Soma S, Shimanuki Y, Nishio K \& Fukuchi Y 2003 Osteopontin overproduced by tumor cells acts as a potent angiogenic factor contributing to tumor growth. Cancer Letters 198 107-117. (doi:10.1016/S0304-3835(03) 00286-6)

Johnson GA, Spencer TE, Burghardt RC \& Bazer FW 1999 Ovine osteopontin: I. Cloning and expression of messenger ribonucleic acid in the uterus during the periimplantation. Biology of Reproduction 6 884-891.

Johnson GA, Spencer TE, Burghardt RC, Taylor KM, Gray CA \& Bazer FW 2000 Progesterone modulation of osteopontin gene expression in the ovine uterus. Biology of Reproduction 62 1315-1321. (doi:10.1095/ biolreprod62.5.1315)

Johnson GA, Bazer FW, Jaeger LA, Ka H, Garlow JE, Pfarrer C, Spencer TE \& Burghardt RC 2001 Muc-1, integrin, and osteopontin expression during the implantation cascade in sheep. Biology of Reproduction 65 820-828. (doi:10.1095/biolreprod65.3.820)

Johnson GA, Burghardt RC, Bazer FW \& Spencer TE 2003 Osteopontin: roles in implantation and placentation. Biology of Reproduction 69 1458-1471. (doi:10.1095/biolreprod.103.020651)

Kim JH, Skates SJ, Uede T, Wong KK, Schorge JO, Feltmate CM, Berkowitz RS, Cramer DW \& Mok SC 2002 Osteopontin as a potential diagnostic biomarker for ovarian cancer. Journal of the American Medical Association 287 1671-1679. (doi:10.1001/jama.287.13.1671)

Kim J, Erikson DW, Burghardt RC, Spencer TE, Wu G, Bayless KJ, Johnson GA \& Bazer FW 2010 Secreted phosphoprotein 1 binds integrins 
to initiate multiple cell signaling pathways, including FRAP1/mTOR, to support attachment and force-generated migration of trophectoderm cells. Matrix Biology 29 369-382. (doi:10.1016/j.matbio.2010.04.001)

Lesley J, Hyman R \& Kincade PW 1993 CD44 and its interaction with extracellular matrix. Advances in Immunology 54 271-335.

Mackay CR \& Hein WR 1989 A large proportion of bovine T cells express the gamma delta $T$ cell receptor and show a distinct tissue distribution and surface phenotype. International Immunology 1 540-545. (doi:10.1093/intimm/1.5.540)

Miyake $\mathrm{Y}$, Matsumoto $\mathrm{H}$, Yokoo M, Miyazawa K, Kimura N, Tunjung WA, Shimizu T, Sasada H, Aso H, Yamaguchi T et al. 2006 Expression and glycosylation with polylactosamine of CD44 antigen on macrophages during follicular atresia in pig ovaries. Biology of Reproduction $\mathbf{7 4}$ 501-510. (doi:10.1095/biolreprod.105.045641)

Ndiaye K, Poole DH \& Pate JL 2008 Expression and regulation of functional oxytocin receptors in bovine T lymphocytes. Biology of Reproduction 78 786-793. (doi:10.1095/biolreprod.107.065938)

Niswender G, Juengel J, Silva P, Rollyson M \& McIntush E 2000 Mechanisms controlling the function and life span of the corpus luteum. Physiological Reviews $\mathbf{8 0} 1-29$.

O'Regan A \& Berman JS 2000 Osteopontin: a key cytokine in cell-mediated and granulomatous inflammation. International Journal of Experimental Pathology 81 373-390. (doi:10.1046/j.1365-2613.2000.00163.x)

O'Regan AW, Chupp GL, Lowry JA, Goetschkes M, Mulligan N \& Berman JS 1999 Osteopontin is associated with T cells in sarcoid granulomas and has T cell adhesive and cytokine-like properties in vitro. Journal of Immunology 162 1024-1031.

Patarca R, Freeman GJ, Singh RP, Wei FY, Durfee T, Blattner F, Regnier DC, Kozak CA, Mock BA \& Morse HC 1989 Structural and functional studies of the early T lymphocyte activation 1 (Eta-1) gene. Definition of a novel T cell-dependent response associated with genetic resistance to bacterial infection. Journal of Experimental Medicine 170 145-161. (doi:10.1084/ jem.170.1.145)

Pate JL 1993 Isolation and culture of fully differentiated bovine luteal cells. Methods in Toxicology 3B 360-370.

Pate JL 1994 Cellular components involved in luteolysis. Journal of Animal Science 72 1884-1890.

Pate JL \& Condon WA 1989 Regulation of steroidogenesis and cholesterol synthesis by prostaglandin $\mathrm{F}_{2 \alpha}$ and lipoproteins in bovine luteal cells. Journal of Reproduction and Fertility 87 439-446. (doi:10.1530/jrf.0. 0870439)

Pate JL \& Keyes LP 2001 Immune cells in the corpus luteum: friends or foes? Reproduction 122 665-676. (doi:10.1530/rep.0.1220665)

Rowson LE, Tervit R \& Brand A 1972 The use of prostaglandins for synchronization of oestrus in cattle. Journal of Reproduction and Fertility 29 145. (doi:10.1530/jrf.0.0290145)

Sathiyaseelan T \& Baldwin CL 2000 Evaluation of cell replication by bovine $T$ cells in polyclonally activated cultures using carboxyfluorescein succinimidyl ester (CFSE) loading and flow cytometric analysis. Research in Veterinary Science 69 275-281. (doi:10.1053/ rvsc.2000.0429)

Senger DR, Perruzzi CA, Papadopoulos-Sergiou A \& Van de Water L 1994 Adhesive properties of osteopontin: regulation by a naturally occurring thrombin-cleavage in close proximity to the GRGDS cell-binding domain. Molecular Biology of the Cell 5 565-574. (doi:10.1091/mbc. 5.5.565)

Silva PJ, Juengel JL, Rollyson MK \& Niswender GD 2000 Prostaglandin metabolism in the ovine corpus luteum: catabolism of prostaglandin $\mathrm{F}(2 \alpha)(\mathrm{PGF}(2 \alpha))$ coincides with resistance of the corpus luteum to PGF $(2 \alpha)$. Biology of Reproduction 63 1229-1236. (doi:10.1095/ biolreprod63.5.1229)

Silvester LM \& Luck MR 1999 Distribution of extracellular matrix components in the developing ruminant corpus luteum: a wound repair hypothesis for luteinization. Journal of Reproduction and Fertility $\mathbf{1 1 6}$ 187-198. (doi:10.1530/jrf.0.1160187)
Smith MF, McIntush EW, Ricke WA, Kojima FN \& Smith GW 1999 Regulation of ovarian extracellular matrix remodelling by metalloproteinases and their tissue inhibitors: effects on follicular development, ovulation and luteal function. Journal of Reproduction and Fertility. Supplement 54 367-381.

Sodek J, Ganss B \& McKee MD 2000 Osteopontin. Critical Reviews in Oral Biology and Medicine 11 279-303. (doi:10.1177/1045441100011 0030101)

Takahashi F, Akutagawa S, Fukumoto H, Tsukiyama S, Ohe Y, Takahashi K, Fukuchi Y, Saijo N \& Nishio K 2002 Osteopontin induces angiogenesis of murine neuroblastoma cells in mice. International Journal of Cancer $\mathbf{9 8}$ 707-712. (doi:10.1002/ijc.10261)

Townson DH \& Pate JL 1996 Mechanism of action of TNF- $\alpha$-stimulated prostaglandin production in cultured bovine luteal cells. Prostaglandins 52 361-373.

Townson DH, O'Connor CL \& Pru JK 2002 Expression of monocyte chemoattractant protein-1 and distribution of immune cell populations in the bovine corpus luteum throughout the estrous cycle. Biology of Reproduction 66 361-366. (doi:10.1095/biolreprod66.2.361)

Tsai SJ \& Wiltbank MC 1998 Prostaglandin $F_{2 \alpha}$ regulates distinct physiological changes in early and mid-cycle bovine corpora lutea. Biology of Reproduction 58 346-352. (doi:10.1095/biolreprod58.2.346)

Vivers S, Heasman SJ, Hart SP \& Dransfield I 2004 Divalent cationdependent and -independent augmentation of macrophage phagocytosis of apoptotic neutrophils by CD44 antibody. Clinical and Experimental Immunology 138 447-452. (doi:10.1111/j.1365-2249. 2004.02638.x)

Wai PY, Mi Z, Guo H, Sarraf-Yazdi S, Gao C, Wei J, Marroquin CE, Clary B \& Kuo PC 2005 Osteopontin silencing by small interfering RNA suppresses in vitro and in vivo CT26 murine colon adenocarcinoma metastasis. Carcinogenesis 26 741-751. (doi:10.1093/carcin/bgi027)

Wallace M, Malkovsky M \& Carding SR 1995 Gamma/delta T lymphocytes in viral infections. Journal of Leukocyte Biology 58 277-283.

Weber GF, Ashkar S \& Cantor H 1996 Interaction between CD44 and osteopontin as a potential basis for metastasis formation. Proceedings of the Association of American Physicians 109 1-9.

Wright MF, Sayre B, Keith Inskeep EK \& Flores JA 2001 Prostaglandin F $(2 \alpha)$ regulation of the bovine corpus luteum endothelin system during the early and midluteal phase. Biology of Reproduction 65 1710-1177. (doi:10.1095/biolreprod65.6.1710)

Xie Y, Nishi S, Iguchi S, Imai N, Sakatsume M, Saito A, Ikegame M, lino N, Shimada H, Ueno M et al. 2001 Expression of osteopontin in gentamicininduced acute tubular necrosis and its recovery process. Kidney International 59 959-974. (doi:10.1046/j.1523-1755.2001. 059003959.x)

Zhang Q, Domenicucci C, Goldberg HA, Wrana JL \& Sodek J 1990 Characterization of fetal porcine bone sialoproteins, secreted phosphoprotein I (SPPI, osteopontin), bone sialoprotein, and a 23-kDa glycoprotein. Demonstration that the 23-kDa glycoprotein is derived from the carboxyl terminus of SPPI. Journal of Biological Chemistry 265 7583-7589.

Zheng J, Fricke P, Reynolds L \& Redmer D 1994 Evaluation of growth, cell proliferation, and cell death in bovine corpora lutea throughout the estrous cycle. Biology of Reproduction 51 623-632. (doi:10.1095/ biolreprod51.4.623)

Received 3 May 2013

First decision 3 June 2013

Revised manuscript received 16 August 2013

Accepted 9 September 2013 